\title{
IMPLEMENTASI MANAJEMEN FASILITAS KONSTRUKSI SEMENTARA PADA PROYEK PEMBANGUNAN RUMAH SAKIT EDELWEISS DI KOTA BANDUNG
}

\author{
Gabriella Laurencia Liman ${ }^{1}$, Yohanes Lim Dwi Adianto ${ }^{2}$, Mia Wimala $^{3}$ \\ Universitas Katolik Parahyangan, Jurusan Teknik Sipil. Jalan Ciumbuleuit 94, Bandung. \\ Email: gabriella.laurencia98@gmail.com ${ }^{1}$ adi@unpar.ac.id ${ }^{2}$, miasoejoso@unpar.ac.id ${ }^{3}$
}

DOI: http://dx.doi.org/10.29103/tj.v10i2.295

(Received: April 2020 / Revised: August 2020 / Accepted: August 2020)

\begin{abstract}
Abstrak
Keberadaan fasilitas sementara yang dapat berkontribusi pada keberhasilan proyek konstruksi sering diabaikan di Indonesia, hal ini ditunjukkan dengan tidak adanya standar dan pedoman yang mengatur secara khusus tentang fasilitas tersebut. Penelitian ini bertujuan untuk menganalisis penerapan manajemen fasilitas sementara pada proyek pembangunan rumah sakit Edelweiss di Bandung, termasuk mengidentifikasi ukuran dan spesifikasi serta memperkirakan biaya totalnya. Data penelitian diperoleh melalui wawancara tidak terstruktur, observasi dan pengukuran di lapangan, serta studi dokumentasi. Kombinasi analisis kualitatif dan kuantitatif dilakukan untuk memeriksa secara rinci manajemen fasilitas sementara. Estimasi biaya dilakukan untuk merumuskan biaya yang telah dan perlu disediakan oleh kontraktor. Selanjutnya, perbandingan estimasi biaya menggunakan harga penawaran kontraktor dan analisis harga satuan dari standar pemerintah juga dilakukan untuk menentukan perbedaan antara keduanya sebagai referensi penggunaan di masa depan. Hasil penelitian menunjukkan bahwa penerapan manajemen fasilitas sementara di konstruksi RS Edelweiss masih belum efektif. Penambahan yang signifikan dalam biaya fasilitas sementara hingga 295,23\% disebabkan karena perencanaan yang belum memadai, serta perbedaan koefisien material dan pekerja, pemilihan material, besaran upah tenaga kerja, dan harga material yang digunakan dalam perhitungan.
\end{abstract}

Kata kunci: fasilitas sementara, anggaran biaya, spesifikasi, standar ukuran

\begin{abstract}
The existence of temporary construction facilities that could contribute to the success of construction projects is often neglected in Indonesia. It is indicated by the absence of standards and guidelines that govern, specifically these facilities. This research aims to analyze the implementation of temporary facility management in the construction of Edelweiss hospital in Bandung. This includes identifying the size and specification and estimating the costs of temporary facilities. Data obtained through unstructured interviews, site observations and measurements, as well as documentation studies. Mixed method analysis was used to examine in detail the conditions related to on-site temporary facility management. Cost estimation was carried out to formulate the costs that have been and need to be provided by the contractor. Furthermore, a comparison of cost estimation using contractor bid prices and unit price analysis from the government standard was also conducted to determine the difference between the two as a reference for future use. The results show that the implementation of temporary facility management in Edelweiss hospital construction was still ineffective. The significant increase in the cost up to $295.23 \%$ was due to inadequate planning, and differences in material and worker coefficients, material selection, labor wage rates, and material prices used in the calculation.
\end{abstract}

Keywords: temporary construction facility, cost budget, specification, standard size

Implementasi Manajemen Fasilitas Konstruksi Sementara Pada Proyek Pembangunan Rumah Sakit Edelweiss di Kota Bandung - Gabriella Laurencia Liman, Yohanes Lim Dwi Adianto, Mia Wimala 


\section{Latar Belakang}

Perencanaan tata letak (site layout) konstruksi meliputi identifikasi, pengukuran dan penempatan fasilitas konstruksi (temporary construction facilities) sementara yang dibutuhkan selama proyek berlangsung (Elbeltagi, 1987). Fasilitas yang dimaksud antara lain tempat tinggal sementara para pekerja, toilet, musala, gudang, kantin, pos satpam, kantor sementara, dan fasilitas penunjang kesejahteraan, kesehatan dan P3K, parkir (Khalafallah and El-Rayes, 2006). Fasilitas sementara ini berfungsi untuk menunjang kesuksesan dan kelancaran kegiatan proyek, serta meningkatkan produktivitas kerja (Wijaya and Putri, 2016) (Abotaleb, Nassar and Hosny, 2015) (Calis and Yuksel, 2019) (Oral et al., 2018). Oleh karena itu, perencanaannya harus memperhatikan faktor kualitas kerja, efisiensi waktu, keselamatan, keamanan, kenyamanan, dan kondisi kesehatan bagi pekerja, serta pertimbangan aspek keberlanjutan dalam konsepsi, produksinya dan penggunaannya, yang mana memungkinkan untuk digunakan kembali setelah dibongkar (Hatem, 2020) (Dias and Serra, 2013). Semua itu harus seiring dengan tujuan pembangunan, baik dari segi waktu, biaya, maupun mutu.

Sampai saat ini, belum ada pedoman atau standar yang baku berkaitan dengan fasilitas sementara di proyek konstruksi di Indonesia, begitu juga dengan persentase anggaran biaya terhadap total biaya proyek yang perlu disediakan oleh pihak kontraktor. Seringkali hal ini tidak dianggap terlalu signifikan oleh karena itu umumnya fasilitas sementara ini dibuat seadanya dengan anggaran secukupnya tanpa perhitungan yang tepat, hal ini perlu ditindaklanjuti mengingat fakta bahwa pekerjaan dan fasilitas sementara yang termasuk dalam pekerjaan persiapan dapat memakan biaya hingga 12\% dari total biaya konstruksi, tergantung tipe bangunan, kondisi lapangan, dan ketentuan pemilik bangunan selama durasi pembangunan (Sutt, Lill and Müürsepp, 2013).

Tujuan penelitian ini adalah untuk mengukur sejauh mana implementasi manajemen fasilitas sementara di proyek pembangunan RS Edelweiss, Bandung, termasuk di dalamnya adalah mengidentifikasi ukuran fasilitas sementara yang disediakan di proyek tersebut, membandingkannya dengan standar/pedoman yang berlaku baik di Indonesia maupun di luar negeri, mengestimasi biaya yang diperlukan untuk menyediakan fasilitas sementara, serta menganalisis faktorfaktor yang menjadi pertimbangan dalam pengadaan fasilitas sementara tersebut. Pembangunan RS Edelweiss merupakan studi kasus yang dirasa sesuai karena skalanya yang besar dan kompleks sehingga memerlukan berbagai fasilitas sementara yang lebih detail. Hasil penelitian ini diharapkan mampu memberikan kontribusi bagi pelaku di bidang konstruksi, khususnya kontraktor, konsultan pengawas maupun konsultan manajemen konstruksi (MK) sebagai bahan pertimbangan dalam merencanakan manajemen fasilitas sementara dan menentukan besarnya anggaran biayanya bagi kesuksesan pelaksanaan proyek konstruksi di masa yang akan datang. Kesepakatan antara semua pihak yang terlibat di dalam suatu proyek tentang perencanaan fasilitas sementara di awal tahapan proyek, dapat mengurangi banyak permasalahan yang mungkin terjadi sewaktu pelaksanaan, seperti keterlambatan proyek, penambahan biaya, kerusakan lingkungan dan terlebih lagi kualitas hasil proyek (Song et al., 2018) (Oral et al., 2018).

Implementasi Manajemen Fasilitas Konstruksi Sementara Pada Proyek Pembangunan Rumah Sakit Edelweiss di Kota Bandung - Gabriella Laurencia Liman, Yohanes Lim Dwi Adianto, Mia Wimala 


\section{Metode Penelitian}

\subsection{Pengumpulan Data}

Pengumpulan data untuk penelitian ini dilakukan melalui beberapa metode yaitu wawancara tak terstruktur dengan pihak kontraktor dari pembangunan proyek RS Edelweiss, observasi dan pengukuran di lapangan, serta studi dokumentasi dari data historis kasus-kasus serupa.

\subsection{Analisis Data}

Data yang telah dikumpulkan digunakan dalam analisis untuk mengidentifikasi kelayakan fasilitas sementara yang disediakan oleh pihak kontraktor di proyek tersebut. Analisis estimasi biaya fasilitas sementara yang dilakukan dalam penelitian ini dibedakan menjadi dua model, yakni menggunakan harga penawaran dari rencana anggaran biaya $(\mathrm{RAB})$ pekerjaan persiapan yang diajukan oleh kontraktor, dan menggunakan AHS yang dikeluarkan oleh pemerintah berdasarkan Handbook Standar Nasional Indonesia (SNI): Analisa Biaya Konstruksi 2008 (Badan Standarisasi Nasional, 2008), Lampiran Peraturan Menteri Pekerjaan Umum Dan Perumahan Rakyat Nomor: 28/PRT/M/2016, dan Jurnal Daftar Harga Material dan Upah Kota Bandung 2018 (Nusantara, 2018). Rekomendasi alternatif ukuran dan tata letak (site layout) fasilitas sementara juga akan diberikan sebagai hasil keluaran penelitian ini

\subsection{Implementasi Manajemen Desain Fasilitas Sementara}

Proyek pembangunan RS Edelweiss senilai Rp131.316.730.000,- terletak di Jalan Soekarno Hatta, Kota Bandung. RS Edelweiss merupakan rumah sakit swasta kelas B yang terdiri dari 11 lantai, dan direncanakan untuk memiliki layan unggulan berupa bedah non invasive, cath lab dan stroke center serta trauma healing. Bangunan RS dibagi menjadi dua gedung, yaitu gedung RS yang berada di sayap kiri, dan gedung parkir yang akan berada di sayap kanan. Saat penelitian dilakukan, proyek ini sedang berada dalam proses konstruksi minggu ke-22 sampai dengan 26. Adapun pekerjaan yang sedang berjalan dalam kurun waktu tersebut adalah pekerjaan struktur, arsitektur, dan elektrikal. Proyek dengan luas bangunan sebesar $15.986 \mathrm{~m}^{2}$ ini dilakukan sejak Oktober 2018 hingga Desember 2019. Pihak-pihak yang terlibat dalam proyek pembangunan adalah konsultan perencana, kontraktor pelaksana, konsultan MK, serta beberapa sub kontraktor yang terlibat dalam pekerjaan fondasi, bekisting, pembesian, pengecoran, pemasangan bata dan plumbing, serta Mekanikal dan Elektrikal (M\&E).

Kontraktor pelaksana dan konsultan MK diketahui terlibat sejak awal konstruksi dalam penentuan desain fasilitas sementara. Kontraktor diberi wewenang oleh konsultan MK untuk menentukan fasilitas sementara yang diperlukan di proyek ini, dan merancang site layout berikut ukurannya. Selanjutnya, konsultan MK bertanggung jawab untuk memeriksa kembali rancangan yang dibuat oleh kontraktor dan menyesuaikannya dengan ketentuan yang ditetapkan pada dokumen Rencana Kerja dan Syarat-syarat (RKS). Apabila disetujui kedua belah pihak, maka rancangan tersebut akan diimplementasikan di lapangan. Pihak kontraktor mengakui bahwa dalam perencanaannya, berbagai macam fasilitas sementara tidak mempertimbangkan standar/pedoman khusus, melainkan hanya didasarkan pada perkiraan sesaat yang dirasa dapat menunjang

Implementasi Manajemen Fasilitas Konstruksi Sementara Pada Proyek Pembangunan Rumah Sakit Edelweiss di Kota Bandung - Gabriella Laurencia Liman, Yohanes Lim Dwi Adianto, Mia Wimala 
kelancaran proses pembangunan proyek dengan memanfaatkan lahan yang ada, oleh sebab itu, terdapat beberapa penambahan fasilitas sementara seiring dengan kemajuan pekerjaan proyek, begitu juga dengan perubahan ukuran.

Rancangan awal yang diajukan oleh kontraktor meliputi 14 jenis fasilitas sementara, yang terdiri dari area induksi dan security, area berkumpul, kantor kontraktor, kantor konsultan $\mathrm{MK}$, gudang, area parkir, cleaning area, reinforcement area, musala, formwork area, power house, WC umum, dan dua smoking area dengan total luas sekitar $693 \mathrm{~m}^{2}$. Pendataan ulang yang dilakukan sebagai hasil observasi langsung di lapangan berhasil mengidentifikasi beberapa tambahan fasilitas sementara yaitu gudang, WC tamu, kantor direksi, kantor K3 dan klinik, kantin, warung kopi, urinoir pekerja, dan ruang komunal. Hal ini menyebabkan penambahan luas fasilitas sementara di lapangan menjadi 831,03 $\mathrm{m}^{2}$. Selanjutnya, analisis ukuran fasilitas sementara dilakukan dengan mempertimbangkan tiga aspek yakni: 1) ketentuan yang terdapat pada pustaka acuan, 2) kebutuhan seseorang dalam suatu ruang, dan 3) jumlah orang yang direncanakan untuk menempati ruang tersebut.

Berdasarkan peta rencana tata dan pola ruang dalam Peraturan Daerah Kota Bandung No. 18 Tahun 2011 tentang Rencana Tata Ruang Wilayah Kota Bandung Tahun 2011-2031, proyek RS Edelweiss termasuk ke dalam Sub Wilayah Kota (SWK) Kondon, Kawasan Budidaya Perkantoran. Namun pada kenyataannya, proyek ini masuk ke dalam klasifikasi Kawasan Perdagangan dan Jasa Skala Wilayah dan Kota. Lokasi proyek yang berada di jalan arteri mengakibatkan KDB maksimum sebesar 70\% dan KLB maksimum sebesar 3,5 harus diterapkan pada bangunan dengan luas total kurang dari $40.000 \mathrm{~m}^{2}$. Proyek RS Edelweiss telah memenuhi persyaratan pemanfaatan lahan sebesar 45,24\%, lebih kecil dari KDB maksimum. Hal ini berarti, terdapat sisa lahan seluas 2.815 $\mathrm{m}^{2}(54,75 \%)$ yang dapat dimanfaatkan untuk alokasi penempatan fasilitas sementara.

Tabel 1 Pengelompokkan fasilitas sementara

\begin{tabular}{cll}
\hline Kode Huruf & Jenis Fasilitas Sementara & Bentuk \\
\hline A & Induksi dan Security & Bangunan Fisik \\
\hline B & Area Berkumpul & Ruang Bebas \\
\hline C & Kantor Sementara & Bangunan Fisik \\
\hline D & Gudang & Bangunan Fisik \\
\hline E & Area Parkir & Ruang Bebas \\
\hline F & Cleaning Area & Ruang Bebas \\
\hline G & Reinforcement Area & Ruang Bebas \\
\hline H & Musala & Bangunan Fisik \\
\hline I & Formwork Area & Ruang Bebas \\
\hline J & Power House & Ruang Bebas \\
\hline K & Toilet (WC) & Bangunan Fisik \\
\hline L & Smoking Area & Ruang Bebas \\
\hline M & Kantin & Bangunan Fisik \\
\hline N & Ruang Komunal & Bangunan Fisik \\
\hline
\end{tabular}

Tabel 1 menunjukkan pengelompokkan jenis fasilitas sementara berdasarkan kode huruf yang diterapkan pada proyek RS Edelweiss. Fasilitas dengan kode A, $\mathrm{C}, \mathrm{D}, \mathrm{H}, \mathrm{K}, \mathrm{L}, \mathrm{M}$, dan $\mathrm{N}$ merupakan fasilitas sementara yang nampak secara fisik dalam wujud bangunan sementara, sekalipun sederhana. Fasilitas seperti kantor

Implementasi Manajemen Fasilitas Konstruksi Sementara Pada Proyek Pembangunan Rumah Sakit Edelweiss di Kota Bandung - Gabriella Laurencia Liman, Yohanes Lim Dwi Adianto, Mia Wimala 
sementara, WC staf kantor dan tamu, gudang, dan ruang komunal berupa pos operator memiliki tinggi bangunan rata-rata sekitar $2,5 \mathrm{~m}$, sedangkan fasilitas seperti area induksi dan security, WC pekerja, musala pekerja, smoking area, kantin, dan pos untuk tukang bor memiliki tinggi ruang rata-rata sekitar $2 \mathrm{~m}$. Fasilitas lainnya yakni B, E, F, G, dan I merupakan fasilitas yang hanya memerlukan seluas lahan untuk pengadaannya. Lahan peruntukan fasilitas sementara jenis ini sangat mungkin dipakai secara tumpang tindih guna pemenuhan aktivitas lain yang menunjang kemajuan proyek konstruksi.

\section{Hasil dan Pembahasan}

\subsection{Fasilitas Sementara}

\subsubsection{Area Induksi dan Security (A)}

Sesuai dengan RKS yang berlaku pada proyek ini, kontraktor telah merancang area induksi dan security seluas $17,65 \mathrm{~m}^{2}$. Pada implementasinya di lapangan, fasilitas A ini dibagi menjadi dua yaitu A1 dan A2. A1 terdiri atas pos satpam $(1,8 \mathrm{~m} \times 1,6 \mathrm{~m})$ dan area induksi $(3,2 \mathrm{~m} \times 1,6 \mathrm{~m})$. Jumlah satpam yang disediakan adalah sebanyak enam orang dengan pembagian shift kerja per 12 jam. Setiap harinya, pos satpam biasa dihuni oleh dua orang satpam. Area induksi merupakan fasilitas yang direncanakan untuk pengarahan alat pelindung diri (APD) sehingga tamu telah diperlengkapi oleh APD sebelum masuk ke area proyek konstruksi. Namun pada kenyataannya, area induksi ini seringkali hanya digunakan sebagai tempat untuk para satpam beristirahat atau menerima tamu berupa perwakilan warga sekitar proyek. Pihak-pihak yang tidak berkaitan dengan proyek seharusnya dilarang memasuki area proyek. Satpam sebagai penjaga keamanan berwenang untuk menolak kehadiran tamu tersebut apalagi jika memang tidak berhubungan dengan proyek. Selain mengganggu produktivitas kerja para satpam, kehadiran tamu yang demikian juga meningkatkan potensi kecelakaan terhadap tamu yang bersangkutan. Dengan teori kebutuhan ruang satpam yang diperlukan adalah sebesar $2 \mathrm{~m}^{2}$ per orang, dengan memperhitungkan kebutuhan sirkulasi sebesar 20\% untuk ruang keamanan (Neufert and Neufert, 2012), maka luas pos satpam yang diperlukan adalah sebesar $4,8 \mathrm{~m}^{2}$. Berdasarkan perhitungan tersebut, maka luas pos satpam sebesar $2,88 \mathrm{~m}^{2}$ yang ada di proyek ini adalah kurang luas dalam mengakomodasi kebutuhan dua orang satpam.

\subsubsection{Kantor Sementara $(C)$}

Pada RKS yang telah disepakati, kontraktor diminta untuk menyediakan kantor pelaksana di dalam kawasan proyek. Pada pelaksanaannya, kontraktor membuat lima jenis kantor yang terdiri dari kantor kontraktor (C1), kantor konsultan MK (C2), kantor direksi (C3), kantor kesehatan dan keselamatan kerja (K3) dan klinik (C4), dan kantor sub kontraktor formwork (C5). Seluruh kantor sementara bersifat site-built atau dibangun langsung di lokasi proyek. Kantor C1 sehari-hari ditempati oleh sepuluh orang yang merupakan staf kantor kontraktor, manakala kantor C2 ditempati oleh delapan orang staf MK. Kantor C3 direncanakan untuk ditempati satu sampai dua orang, namun pada pelaksanaannya, kantor ini tidak pernah ditempati oleh siapapun dikarenakan ruang tersebut diperuntukkan bagi penggunaan oleh staf konsultan perencana. Kantor C4 biasa ditempati oleh dua orang, yakni safety supervisor dan supervisor,

Implementasi Manajemen Fasilitas Konstruksi Sementara Pada Proyek Pembangunan Rumah Sakit Edelweiss di Kota Bandung - Gabriella Laurencia Liman, Yohanes Lim Dwi Adianto, Mia Wimala 
dan kantor C5 ditempati oleh orang dari sub kontraktor bekisting berjumlah tiga orang. Dengan asumsi jumlah pengguna setiap jenis kantor, dan teori kebutuhan ruang perlu pada kantor proyek yaitu sebesar $3,7 \mathrm{~m}^{2}$ per orang (Chudley and Greeno, 2014), maka diketahui bahwa hanya satu dari lima kantor tersebut, yaitu kantor C2 yang mempunyai luasan lebih kecil dari luasan yang disyaratkan. Jika jumlah pekerja kurang dari 150 orang, disarankan bahwa ruang kantor kontraktor perlu memiliki peralatan pertolongan pertama pada kecelakaan (P3K) (Sutt, Lill and Müürsepp, 2013). Termasuk di dalamnya adalah tambahan sebanyak dua orang pekerja, yaitu safety supervisor dan supervisor yang dapat bergabung dalam kantor kontraktor karena divisi Pertolongan Pertama Pada Kecelakaan (P3K) berada di bawah naungan kontraktor dalam proyek ini. Luas kantor $\mathrm{C} 1$ yang dibangun masih memenuhi persyaratan jika tambahan pekerja tersebut dilakukan.

\subsubsection{Gudang (D)}

Kontraktor diminta menyediakan gudang sebagai tempat penyimpanan material konstruksi seperti pasir, koral, besi beton, bata dan lain sebagainya. Khusus untuk material semen, lantai di gudang tersebut diminta untuk bebas dari kelembaban udara dan semen harus diletakkan minimal $30 \mathrm{~cm}$ di atas permukaan lantai plesteran. Dalam site layout fasilitas sementara yang direncanakan, gudang dibangun sementara dalam satu bangunan ukuran 29,7 $\mathrm{m}^{2}$, Pada pelaksanaannya, gudang dibangun dibedakan menjadi gudang bahan dan gudang alat. Gudang bahan $5,5 \mathrm{~m} \mathrm{x} 4 \mathrm{~m}$ untuk penyimpanan zak semen, compound, serta beberapa ember dan selang. Gudang alat berukuran 4,2 $\mathrm{m} \mathrm{x} 4 \mathrm{~m}$ disediakan untuk alat-alat seperti bor, bar cutter, drum, pipa, dan mini genset. Material konstruksi lain tidak direncanakan memiliki penyimpanan khusus karena material didatangkan dan langsung dipergunakan. Berdasarkan hasil observasi tidak ada upaya untuk membuat semen bebas dari kelembaban udara seperti yang disyaratkan.

Akibat keterbatasan data perihal inventaris material dan logistik proyek, maka dalam perhitungan kapasitas gudang akan digunakan asumsi jumlah zak semen per kedatangan. Setiap kedatangan semen sebanyak 1 delivery order (DO) yang dalam proyek ini setara dengan $250 \mathrm{zak}$, dengan repeat order yang dilakukan saat persediaan tersisa sebanyak 10\%. Supplier menyamakan ukuran 1 DO setara dengan beban seberat 8 hingga 10 ton. Dengan demikian, beberapa supplier menyanggupi pengiriman sebanyak 250 zak untuk semen ukuran $40 \mathrm{~kg}$, dan 200 zak untuk semen ukuran $50 \mathrm{~kg}$. Ukuran zak semen isi $50 \mathrm{~kg}$ adalah $10 \mathrm{~cm}$ x $40 \mathrm{~cm}$ x $60 \mathrm{~cm}$. Ukuran tersebut dijadikan acuan dalam perhitungan kebutuhan semen dalam kegiatan konstruksi pada umumnya. Koefisien 0,8 digunakan sebagai pendekatan perbandingan ukuran antara zak semen $40 \mathrm{~kg}$ dan $50 \mathrm{~kg}$. Perhitungan akan kebutuhan luas gudang bahan dapat dilakukan dengan mengkalikan kapasitas jumlah zak semen dengan luas kebutuhan per zak semen dan $110 \%$. Pada kenyataannya, semen akan ditumpukkan ke atas sehingga perlu dilakukan perhitungan dengan memperhatikan tinggi tumpukan umumnya sekitar 8 sampai dengan 10 zak semen. Volume gudang yang disediakan adalah lebih besar dari volume yang diperlukan sehingga dapat dikatakan gudang tersebut dapat menampung material semen dengan baik dari segi kapasitas. Volume ruang tersisa dapat dimanfaatkan untuk menempatkan material lain yang juga sensitif terhadap perubahan cuaca, serta rawan pencurian.

Implementasi Manajemen Fasilitas Konstruksi Sementara Pada Proyek Pembangunan Rumah Sakit Edelweiss di Kota Bandung - Gabriella Laurencia Liman, Yohanes Lim Dwi Adianto, Mia Wimala 


\subsubsection{Musala (H)}

Kewajiban pengadaan fasilitas berupa musala tidak tercantum dalam RKS, tetapi pada akhirnya, fasilitas ini dirasakan perlu untuk proyek ini karena sebagian pekerjanya adalah muslim. Pihak kontraktor membangun dua musala yaitu untuk para staf (H1) yang terletak di antara WC staf kantor dan kantor kontraktor yang merupakan bekas pos satpam, dan untuk para pekerja $(\mathrm{H} 2)$ yang berupa bangunan sederhana seperti gubuk buatan para pekerja. Sumber pustaka yang dijadikan acuan dalam penelitian ini merupakan pustaka yang bersumber dari negara-negara barat, yang mana mayoritas penduduknya adalah non-muslim. Namun demikian, penggunaan ruang maksimum seorang manusia saat duduk dan bersujud, serta kebutuhan sirkulasi sebesar 20\% seperti yang ditunjukkan pada Gambar 2 dapat menggunakan acuan umum (Neufert and Neufert, 2012). Dengan asumsi penggunaan ruang tersebut, maka saat seorang muslim melakukan salat membutuhkan ruang seluas $1,23 \mathrm{~m}^{2}$.

Dari hasil wawancara tak berstruktur terhadap para staf serta pekerja, diperoleh informasi bahwa setiap harinya, para staf dan pekerja biasa melakukan salat saat istirahat makan siang sekitar pukul 12.00-13.00 untuk salat dzuhur dan sekitar pukul 15.00-16.00 untuk salat ashr. Selama kurun waktu salat Dzuhur, hampir seluruh staf melakukan salat. Sembari mencari makan di luar area konstruksi, terkadang para staf memilih untuk melakukan salat di masjid terdekat. Sementara dari sisi pekerja, umumnya ada sekitar lima orang untuk salat dzuhur dan hanya sekitar dua hingga tiga orang yang melakukan salat ashr per kloternya. Penggunaan musala dilakukan secara bergantian dan memakan waktu sekitar 10 menit per kloternya. Dengan luas $29,90 \mathrm{~m}^{2}$, daya tampung musala per kloternya adalah 24 orang untuk H1, dan tiga orang untuk H2. Daya tampung musala H1, dan $\mathrm{H} 2$ per jam secara berturutan adalah 144 orang/jam, dan 18 orang/jam. Apabila diasumsikan seluruh staf datang ke proyek, yakni 19 orang staf kontraktor, sembilan orang staf MK, dua orang staf konsultan, dua orang satpam, dan 98 orang pekerja yang ada di proyek (saat kemajuan pekerjaan mingguan tertinggi), dan seluruhnya merupakan muslim dan hendak beribadah, maka total pengguna adalah 130 orang. Dengan kapasitas sebesar 144 orang/jam, musala staf sudah cukup untuk mengakomodasi kebutuhan musala untuk seluruh pekerja.

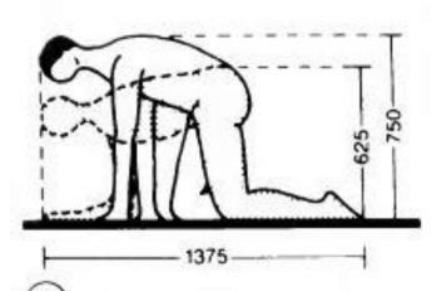

(1)

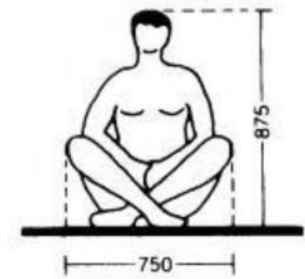

(2)

Gambar 1 Kebutuhan ruang saat bersujud dan duduk (Neufert and Neufert, 2012)

\subsubsection{Toilet/WC $(\mathbf{K})$}

Pada proyek ini, terdapat dua jenis toilet yang disediakan baik untuk para staf dan tamu (K1), para pekerja (K2). K1 berjumlah 2 buah, dan K2 4 buah. Persyaratan toilet pada RKS yang ditetapkan secukupnya untuk semua yang terlibat di proyek, dengan perbandingan 1 unit toilet untuk 20 orang. Persyaratan

Implementasi Manajemen Fasilitas Konstruksi Sementara Pada Proyek Pembangunan Rumah Sakit Edelweiss di Kota Bandung - Gabriella Laurencia Liman, Yohanes Lim Dwi Adianto, Mia Wimala 
ini memenuhi ketentuan yang mensyaratkan kapasitas maksimal hingga 25 orang pekerja per unit toilet (Chudley and Greeno, 2014). Pada mulanya, seluruh fasilitas saniter dipusatkan pada K2. Setelah dilakukan pengkajian ulang, toilet K1 baru diputuskan untuk dibangun memenuhi kebutuhan seluruh pihak yang terlibat. Berdasarkan jumlah pekerja tertinggi adalah sebanyak 98 orang pada waktu puncak, ditambah dengan total staf kantor sebanyak 30 orang dan 2 orang satpam, maka jumlah toilet yang diperlukan adalah 7 unit. Dapat disimpulkan bahwa jumlah toilet yang memenuhi syarat adalah jenis K1, sementara itu untuk jenis K2 perlu ditambahkan 1 unit lagi guna mengakomodasi kebutuhan seluruh pekerja.

\subsubsection{Smoking Area (L)}

Smoking Area merupakan fasilitas sementara yang disediakan pada proyekproyek khususnya di Indonesia sebagai solusi atas tingginya kebiasaan merokok para pekerjanya. Idealnya, para pekerja tidak diperkenankan untuk merokok pada area konstruksi disebabkan alasan keselamatan dan kesehatan kerja, namun demikian, dikarenakan sulitnya mengendalikan kebiasaan merokok para pekerja, kontraktor memutuskan untuk membuat smoking area, yaitu L1 yang terletak di sebelah WC pekerja, dan L2 yang terletak di sayap kanan bangunan. Para pekerja diperkenankan merokok dalam area proyek dilakukan di smoking area. Apabila ditemukan pelanggaran, maka pekerja akan diberi teguran lisan untuk pelanggaran pertama. Apabila pelanggaran telah dilakukan sebanyak dua kali, maka pekerja akan diberi teguran tertulis. Kemudian, apabila ditemukan pelanggaran kali ke-3, maka pekerja dikenakan denda. Tidak ada aturan khusus maupun syarat dari RKS mengenai pertimbangan pembuatan smoking area.

\subsubsection{Kantin (M)}

Pada awalnya, pihak kontraktor tidak memasukkan kantin ke dalam pertimbangan manajemen fasilitas sementara, namun akhirnya, terdapat tiga kantin yang disediakan yakni kantin depan (M1), warung kopi (M2), dan kantin belakang (M3). Kantin depan maupun belakang sama-sama menjual komoditi yang sama yakni menu nasi dan lauk pauk, minuman, serta aneka jajanan gorengan. Kantin muncul sebagai inisiatif kontraktor dalam meningkatkan produktivitas para pekerja dengan memangkas waktu yang tidak produktif yang digunakan untuk makan maupun rehat. Fasilitas kantin ini umumnya dimanfaatkan para pekerja terutama pada jam istirahat, namun kenyataannya, beberapa pekerja dan hampir sebagian besar staf kantor memilih untuk membeli makanan dan minuman di luar area sekalipun ada tiga kantin yang tersedia.

\subsubsection{Ruang Komunal (N)}

Ruang komunal awalnya tidak dimasukkan dalam pertimbangan pembuatan fasilitas sementara. Kontraktor hanya diminta menyediakan bedeng pekerja di lokasi yang akan ditentukan konsultan MK dan pihak pemberi tugas. Bedeng sangat diperlukan dalam proyek sebagai tempat persinggahan untuk pekerja beristirahat sementara, mengganti pakaian, maupun makan dan minum. Kenyataannya, bedeng tidak disediakan di lokasi proyek, sekalipun awalnya direncanakan dekat reinforcement area. Ruang komunal yang disediakan khusus pada akhirnya terdiri dari pos untuk operator alat berat (N1), pos untuk tukang bor

Implementasi Manajemen Fasilitas Konstruksi Sementara Pada Proyek Pembangunan Rumah Sakit Edelweiss di Kota Bandung - Gabriella Laurencia Liman, Yohanes Lim Dwi Adianto, Mia Wimala 
(N2), dan ruang komunal (N3), namun dikarenakan luasannya yang tidak terlalu besar, para pekerja sering kali memanfaatkan fasilitas smoking area (L), kantin (M), dan area bangunan yang sedang dibangun untuk beristirahat sementara.

Fasilitas seperti N1 dan N2 bisa dihilangkan jika bedeng pekerja dapat dibuat sedemikan rupa untuk berfungsi sebagai ruang komunal. N3 terletak di antara kantor kontraktor dan kantor konsultan MK berupa ruang kosong dengan peruntukannya yang belum jelas. Sekalipun ruang komunal disediakan pekerja tidak bisa memanfaatkan fasilitas ini untuk istirahat sementara ataupun makan dan minum, karena letak ruang komunal di antara dua kantor, sehingga membuat para pekerja sungkan untuk menggunakannya. Para staf kantor pihak kontraktor maupun konsultan MK juga diketahui tidak pernah memanfaatkan fasilitas ini karena fokus bekerja di kantor masing-masing. Pada jam istirahat, staf juga lebih memilih makan di dalam kantor ataupun mencari makanan di luar area konstruksi. Keberadaan ruang komunal baik N1, N2 dan N3 bisa disubtitusi dengan bedeng guna pemenuhan kebutuhan para pekerja untuk sekedar beristirahat.

\subsubsection{Area Berkumpul (B)}

Fasilitas B merupakan area berkumpul berupa area kosong yang idealnya bersih dari hambatan, kendaraan, maupun material bangunan. Implementasi fasilitas B di lapangan menggunakan area yang terletak di depan komplek kantor konsultan MK, kantor direksi, dan kantor K3. Pemanfaatan fasilitas ini biasa dilakukan pagi hari, saat briefing pekerja. Menurut pendapat tim engineering, fasilitas ini dapat dipakai bertumpang tindih dengan penggunaan lain di proyek.

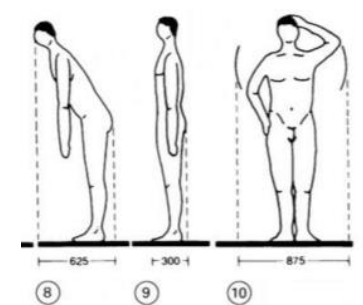

Gambar 2 Kebutuhan ruang saat berdiri (Neufert and Neufert, 2012)

Pertimbangan pengambilan ukuran ruang tersebut berdasarkan keleluasaan bergerak manusia saat posisi berdiri, yaitu seluas $0,6 \mathrm{~m}^{2}$ seperti yang terlihat pada Gambar 2 (Neufert and Neufert, 2012). Apabila digunakan asumsi bahwa jumlah pekerja maksimum mingguan adalah 98 orang pekerja, maka diperlukan area berkumpul seluas $58,8 \mathrm{~m}^{2}$. Desain fasilitas sementara di proyek ini telah memenuhi ketentuan luas minimum yang diperlukan.

\subsubsection{Area Parkir (E)}

Setiap harinya, kendaraan diparkir di area yang berada di depan musala, di depan kantor dan di depan pos satpam. Area di depan musala dan kantor kontraktor biasa diperuntukkan untuk mobil staf proyek, sementara area di depan jajaran kantor konsultan MK, direksi dan K3, dan di depan pos satpam diperuntukkan motor staf proyek dan pekerja. Berdasarkah observasi di lapangan, diketahui bahwa luas total area parkir yang tersedia $147,81 \mathrm{~m}^{2}$. Pendataan jumlah kendaraan yang dimiliki baik staf maupun pekerja tidak pernah dilakukan selama

Implementasi Manajemen Fasilitas Konstruksi Sementara Pada Proyek Pembangunan Rumah Sakit Edelweiss di Kota Bandung - Gabriella Laurencia Liman, Yohanes Lim Dwi Adianto, Mia Wimala 
proyek berlangsung, hal ini mengindikasikan bahwa tidak ada acuan yang digunakan dalam penentuan luasan lahan parkir tersebut. Pendataan diperlukan untuk mengetahui luasan area parkir yang benar-benar dibutuhkan dalam proyek ini, selain juga bermanfaat untuk meminimalisasi potensi pencurian, perusakan dan potensi tertimpa material dan peralatan konstruksi. Keberadaan kendaraan yang parkir di sembarang tempat juga dapat menghambat sirkulasi kendaraan pengangkut material konstruksi masuk ke dalam lokasi proyek. Seringkali yang terjadi di lapangan adalah pada saat kedatangan material, seluruh kendaraan harus dipindahkan ke lahan kosong di dekat proyek, hal ini tentu menambah waktu nonproduktif pekerja proyek dan staf akan lebih baik jika sejak awal, pendataan jumlah kendaraan dan pembatasan jumlah kendaraan yang masuk ke dalam proyek dilakukan. Kontraktor juga dapat mengusahakan penyewaan lahan di sekitar proyek untuk menjawab kebutuhan parkir seluruh staf dan pekerja proyek.

\subsubsection{Cleaning Area (F)}

Kontraktor diminta menyediakan tempat pembersih kendaraan (cleaning pit) yang dilengkapi dengan air bertekanan tinggi. Setiap kendaraan yang keluar dari area konstruksi harus dijamin bersih dan tidak mengotori jalanan umum. Aturan mengenai kebersihan kendaraan ini dilatarbelakangi oleh posisi proyek yang berada di Jalan Nasional yang umumnya dilalui oleh kendaraan dengan kecepatan rata-rata yang tinggi. Kotoran yang berasal dari kendaraan proyek dapat membuat jalan menjadi licin ataupun membuat jalan menjadi tidak rata sehingga membahayakan pengendara kendaraan lain yang melintasi jalan tersebut.

Pada implementasinya, cleaning area yang disediakan hanya berupa lahan dengan ukuran seluas dump truck dan/atau concrete mixer truck yang dilengkapi dengan selang air dan pompa bertenaga tinggi. Aktivitas pembersihan ini biasanya dilakukan hingga pekerjaan pengecoran, yang berarti apabila realisasi pekerjaan sesuai dengan rencana, maka aktivitas akan berakhir di minggu ke-26, namun, pada masa tersebut, ternyata keberadaan cleaning area sudah tidak terlihat. Referensi luasan minimum cleaning area yang perlu disediakan adalah seluas 13,4 $\mathrm{m}^{2}$ untuk sebuah dump truck, dan 19,4 $\mathrm{m}^{2}$ untuk sebuah concrete mixer truck. Berdasarkan hasil perhitungan luasan minimum tersebut, dapat dikatakan bahwa area yang dirancang telah memenuhi persyaratan tersebut.

\subsubsection{Reinforcement Area (G)}

Reinforcement area merupakan area yang digunakan untuk pabrikasi tulangan baja, dan biasanya disediakan sebuah saung kecil yang beratapkan seng gelombang. Hasil pengukuran di lapangan menunjukkan bahwa reinforcement area yang disediakan adalah berbentuk "L" dengan luas $288 \mathrm{~m}^{2}$. Karena keterbatasan data mengenai inventaris material dan logistik proyek, maka tidak dapat diestimasi dengan tepat apakah ukuran lahan yang terukur di lapangan sudah sesuai dengan kapasitas tampung tulangan baja.

\subsubsection{Formwork Area (I)}

Formwork area merupakan area yang digunakan untuk penyimpanan dan juga perakitan scaffolding. Los kerja pada formwork area ditutupi sebagian oleh tripleks, dan seng gelombang sebagai atapnya. Sama halnya seperti reinforcement

Implementasi Manajemen Fasilitas Konstruksi Sementara Pada Proyek Pembangunan Rumah Sakit Edelweiss di Kota Bandung - Gabriella Laurencia Liman, Yohanes Lim Dwi Adianto, Mia Wimala 
area, ketepatan luasan formwork area sebesar $56 \mathrm{~m}^{2}$ yang disediakan di proyek tidak dapat diketahui dengan pasti. Keterbatasan data mengenai inventaris material dan logistik proyek juga menjadi faktor penyebabnya.

\subsubsection{Power House (J)}

Pada proyek ini, power house tidak termasuk ke dalam fasilitas sementara proyek. Hal ini dikarenakan power house, yang terdiri atas gardu listrik portal serta 1 buah bangunan perlengkapan hubung bagi gardu portal ini kelak akan dipakai sebagai sumber listrik bangunan rumah sakit. Instalasi power house ini seluruhnya dikerjakan oleh Perusahaan Listrik Negara (PLN) dan oleh karena itu, tidak termasuk sebagai tanggung jawab pihak kontraktor. Namun demikian, kontraktor tetap harus memperhitungkan ruang yang digunakan untuk power house dalam penentuan site layout fasilitas sementara proyek. Berdasarkan pengukuran di lapangan, area yang disediakan untuk instalasi satu unit power house ini adalah seluas $4 \mathrm{~m}$ x $1 \mathrm{~m}$, atau $4 \mathrm{~m}^{2}$, dengan jarak aman gardu tiang adalah 2,5 m dari sisi terluar konstruksi gardu (PT. PLN, 2010) sehingga luas area total yang disediakan adalah $9 \mathrm{~m}$ x 3,5 m, atau sekitar $31,5 \mathrm{~m}^{2}$.

\subsection{Estimasi Biaya Fasilitas Sementara}

Dalam proyek yang memakan biaya total sebesar Rp131.316.730.000, pekerjaan persiapan secara keseluruhan dianggarkan oleh kontraktor sebesar 2,28\% dari keseluruhan biaya konstruksi. Terdapat tiga item sub pekerjaan dalam pekerjaan persiapan yang menyangkut pengadaan fasilitas sementara di proyek yang berwujud bangunan fisik, yakni pembuatan direksi keet $\left(36 \mathrm{~m}^{2}\right)$, pembuatan gudang bahan $\left(24 \mathrm{~m}^{2}\right)$, dan pembuatan bangsal kerja $\left(24 \mathrm{~m}^{2}\right)$.

Total biaya yang diajukan kontraktor sebesar Rp 23.400.000, yang berarti hanya memiliki bobot $0,78 \%$ dari $\mathrm{RAB}$ pekerjaan persiapan, atau $0,018 \%$ dari total RAB proyek.

Realita yang terjadi di lapangan menunjukkan bahwa jumlah fasilitas sementara yang terbangun secara fisik di proyek ini berjumlah lebih dari tiga item dengan luasan berbeda dan tidak sesuai dengan RAB yang diajukan. Dengan kata lain, terdapat biaya ekstra yang harus dikeluarkan oleh kontraktor guna menyediakan fasilitas sementara lainnya sesuai dengan kesepakatan.

Penelitian ini akan membahas dua model estimasi biaya. Estimasi dengan data biaya dari harga penawaran pekerjaan persiapan diharapkan mampu memberi asumsi yang sama dalam perhitungan biaya fasilitas sementara, sedangkan estimasi biaya menggunakan AHS berdasarkan Handbook Standar Nasional Indonesia (SNI): Analisa Biaya Konstruksi 2008 (Badan Standarisasi Nasional, 2008), Lampiran Peraturan Menteri Pekerjaan Umum dan Perumahan Rakyat Nomor: 28/PRT/M/2016, dan Jurnal Daftar Harga Material dan Upah Kota Bandung 2018 (Nusantara, 2018) digunakan sebagai kontrol atau pembanding apakah harga per satuan yang diajukan oleh kontraktor terlalu tinggi atau terlalu rendah.

Penggunaan Jurnal Daftar Harga Material dan Upah Kota Bandung Tahun 2018 didasarkan atas waktu pengerjaan pekerjaan persiapan yang dimulai pada pertengahan Oktober 2018.

Implementasi Manajemen Fasilitas Konstruksi Sementara Pada Proyek Pembangunan Rumah Sakit Edelweiss di Kota Bandung - Gabriella Laurencia Liman, Yohanes Lim Dwi Adianto, Mia Wimala 


\subsubsection{Estimasi Biaya Pengadaan Fasilitas Sementara Berdasarkan Harga Penawaran Kontraktor untuk Pekerjaan Persiapan}

Fasilitas area induksi dan security, gudang, musala, pos untuk operator, dan kantin memiliki karakteristik yang sama, yakni memanfaatkan ruang yang terbuat dari papan plywood yang ditopang oleh rangka kayu, dan beratapkan seng gelombang. Dengan demikian, beberapa fasilitas ini dapat diasumsikan mengikuti harga satuan pembuatan gudang kerja dan bangsal kerja pada RAB persiapan yakni sebesar Rp150.000/m². Seluruh kantor sementara memiliki karakteristik yang sama, yakni ruang yang terbuat dari sebagian dinding bata merah untuk menopang kusen jendel, dan beratapkan seng gelombang. Beberapa tambahan untuk kantor sementara antara lain adalah plesteran lantai, penerangan tambahan, air conditioner dan kunci ruangan. Fasilitas ini dapat diasumsikan mengikuti harga satuan pembuatan direksi keet pada RAB persiapan yakni sebesar Rp450.000,00/ $\mathrm{m}^{2}$.

Fasilitas musala dan toilet pekerja tidak diperhitungkan dalam perhitungan biaya karena memanfaatkan bangunan lama yang sudah ada. Fasilitas berupa ruang komunal (N3), smoking area, dan pos untuk tukang bor diasumsikan tidak dihitung biaya pembuatannya karena mayoritas disusun dari kayu bambu sebagai penopang, serta seng gelombang sisa sebagai penutup atap. Fasilitas toilet staf dan tamu yang tidak diperhitungkan dalam RAB persiapan diasumsikan mengikuti harga pembuatan fasilitas sementara terbesar yakni pembuatan kantor sebesar $\mathrm{Rp} 450.000 / \mathrm{m}^{2}$. Asumsi pengambilan harga per satuan luas fasilitas toilet staf didasarkan pada realita di lapangan, dimana fasilitas ini merupakan bangunan yang terbuat dari dinding bata yang diplester, diaci, dan dicat. Lantai toilet diberi keramik motif berukuran $20 \mathrm{~cm}$ x $20 \mathrm{~cm}$, manakala dindingnya juga diberi keramik motif berukuran $30 \mathrm{~cm}$ x $30 \mathrm{~cm}$. Menggunakan asumsi seperti tertulis di atas, diperoleh biaya pembuatan fasilitas sementara sebesar Rp69.084.750 dengan rincian seperti pada Tabel 2.

Tabel 2 Estimasi biaya fasilitas sementara dengan biaya penawaran kontraktor

\begin{tabular}{|c|c|c|c|c|}
\hline No & Jenis Pekerjaan & Volume $\left(\mathbf{m}^{2}\right)$ & $\begin{array}{c}\text { Harga Satuan } \\
\text { (Rp) }\end{array}$ & $\begin{array}{c}\text { Jumlah } \\
\text { (Rp) }\end{array}$ \\
\hline 1 & Pembuatan area induksi dan security & 12,64 & 150.000 & 1.896 .000 \\
\hline 2 & Pembuatan kantor sementara & 113,59 & 450.000 & 51.108 .750 \\
\hline 3 & Pembuatan gudang & 38,80 & 150.000 & 5.820 .000 \\
\hline 4 & Pembuatan musala pekerja & 4,20 & 150.000 & 630.000 \\
\hline 5 & Pembuatan toilet staf dan tamu & 6,93 & 450.000 & 3.118 .500 \\
\hline 6 & Pembuatan kantin & 40,69 & 150.000 & 6.103 .500 \\
\hline 7 & Pembuatan pos untuk operator & 2,72 & 150.000 & 408.000 \\
\hline \multicolumn{4}{|c|}{ Biaya Pengadaan Fasilitas Sementara } & 69.084 .750 \\
\hline
\end{tabular}

Dengan biaya awal yang diajukan oleh kontraktor sebesar Rp 23.400.000, maka berarti terdapat penambahan sebesar Rp45.684.750 untuk memenuhi pengadaan seluruh fasilitas sementara. Dengan kata lain, biaya yang diperlukan untuk membuat fasilitas sementara berdasarkan model analisis ini naik hingga $295,23 \%$ dari rencana awal. Perbedaan yang sangat signifikan ini antara lain disebabkan karena perencanaan fasilitas sementara yang kurang matang sejak awal.

Implementasi Manajemen Fasilitas Konstruksi Sementara Pada Proyek Pembangunan Rumah Sakit Edelweiss di Kota Bandung - Gabriella Laurencia Liman, Yohanes Lim Dwi Adianto, Mia Wimala 


\subsubsection{Estimasi Biaya Pengadaan Fasilitas Berdasarkan AHS dan Jurnal Daftar Harga Material dan Upah Kota Bandung 2018}

Terdapat sedikit perbedaan dalam pengelompokan fasilitas sementara dalam perhitungan menggunakan AHS dan model yang digunakan oleh pihak kontraktor, hal ini disebabkan pengelompokan yang disediakan AHS adalah lebih spesifik. Dalam penelitian ini, AHS yang dikeluarkan oleh pemerintah dijadikan sebagai panduan untuk penyesuaian apabila ditemukan ketidaksesuaian penggunaan material konstruksi di lapangan. Selain itu, akibat keterbatasan data proyek yang menyangkut data material dan logistik, maka standar harga yang dipakai dalam perhitungan adalah menggunakan data dari Jurnal Daftar Harga Material dan Upah Kota Bandung Tahun 2018. Peralatan tidak diperhitungkan karena diasumsikan bahwa kontraktor telah memiliki peralatan untuk membangun fasilitas-fasilitas sementara yang ada. Selain itu, overhead dan profit juga tidak diperhitungkan karena nilai kontrak yang diajukan tidak memasukkan profit di dalamnya. Tabel 3 menunjukkan rangkuman estimasi biaya pengadaan fasilitas sementara yang dilakukan. Dengan biaya yang diajukan oleh kontraktor sebesar Rp23.400.000, maka kontraktor perlu menyediakan dana tambahan sebesar Rp219.490.453 Dengan kata lain, biaya yang diperlukan untuk membuat fasilitas sementara berdasarkan model analisis ini naik hingga 938\%.

Dari dua model estimasi biaya pengadaan fasilitas sementara yang dilakukan, dapat disimpulkan bahwa lonjakan biaya terjadi karena kontraktor menentukan harga terlalu rendah. Sebagai contoh, pengajuan penawaran pembuatan kantor sementara sebagai fasilitas yang memiliki luas total bangunan terbesar adalah sebesar Rp450.000/ $\mathrm{m}^{2}$. Jumlah ini sangat kecil dibandingkan dengan hasil perhitungan berdasarkan AHS yaitu sebesar Rp1.163.971/ $\mathrm{m}^{2}$. Selain itu, setelah ditelusuri lebih dalam, toilet staf dan tamu yang terdiri dari perpaduan pekerjaan struktur dan arsitektur memakan biaya per meter persegi terbesar yakni Rp1.798.984, dimana hal yang sama diajukan sebesar $\mathrm{Rp} 450.000 / \mathrm{m}^{2}$ pada harga penawaran kontraktor.

Tabel 3 Estimasi biaya fasilitas sementara berdasarkan AHS dan jurnal daftar harga material dan upah Kota Bandung tahun 2018

\begin{tabular}{llrrr}
\hline No. & \multicolumn{1}{c}{ Uraian Pekerjaan } & $\begin{array}{c}\text { Volume } \\
\left.\text { Pekerjaan } \mathbf{( m}^{\mathbf{2}}\right)\end{array}$ & $\begin{array}{c}\text { Harga Satuan } \\
\text { Pekerjaan }(\mathbf{R p})\end{array}$ & \multicolumn{1}{c}{$\begin{array}{c}\text { Jumlah } \\
(\mathbf{R p})\end{array}$} \\
\hline 1 & Pembuatan area induksi dan security & 12,64 & 994.753 & 12.573 .678 \\
\hline 2 & Pembuatan kantor sementara & 113,59 & 1.163 .971 & 132.215 .475 \\
\hline 3 & Pembuatan gudang & 38,80 & 1.014 .461 & 39.361 .091 \\
\hline 4 & Pembuatan musala pekerja & 4,20 & 970.540 & 4.076 .266 \\
\hline 5 & Pembuatan toilet staf dan tamu & 6,93 & 1.798 .984 & 12.466 .959 \\
\hline 6 & Pembuatan kantin & 40,69 & 970.540 & 39.491 .256 \\
\hline 7 & Pembuatan pos untuk operator & 2,72 & 994.753 & 2.705 .728 \\
\hline & & Biaya Pengadaan Fasilitas Sementara & $\mathbf{2 4 2 . 8 9 0 . 4 5 3}$ \\
\hline
\end{tabular}

Perbedaan signifikan diantara kedua model estimasi biaya disebabkan oleh beberapa faktor seperti koefisien material dan pekerja, pemilihan material, besaran upah tenaga kerja, dan harga material. Dalam penerapannya, kontraktor diperbolehkan memodifikasi beberapa faktor tersebut dalam pembuatan RAB sesuai dengan asumsi pribadi dan pengalamannya dalam dunia konstruksi.

Implementasi Manajemen Fasilitas Konstruksi Sementara Pada Proyek Pembangunan Rumah Sakit Edelweiss di Kota Bandung - Gabriella Laurencia Liman, Yohanes Lim Dwi Adianto, Mia Wimala 
Di Indonesia, peraturan, dan standar/pedoman seputar kesehatan, keselamatan dan keamanan dalam lingkungan kerja konstruksi memang masih lemah, dan belum mampu melindungi seluruh hak pekerja. Oleh karena itu, kasus besaran biaya untuk fasilitas sementara yang tidak signifikan terhadap total biaya proyek, dan penambahan biaya akibat perencanaan yang kurang matang seperti pada proyek ini masing seringkali dijumpai. Hal ini agak berbeda dengan beberapa negara seperti Inggris, maupun Singapura yang telah memiliki standar yang lebih jelas. Pemerintah Inggris telah menetapkan Construction (Design and Management) Regulation 2015 (Health \& Safety Executive, 2015) yang di dalamnya memuat sejumlah ketentuan mengenai persyaratan kesejahteraan minimum yang diperlukan untuk proyek konstruksi. Serupa dengan pemerintah Inggris, pemerintah Singapura, juga telah mengeluarkan Building Control Act yang di dalamnya memuat pasal Building Control (Temporary Buildings) Regulations 2018 (Building and Construction Authority (BCA), 2018). Peraturanperaturan ini mengatur tentang pengadaan sejumlah fasilitas sementara yang perlu disediakan dalam suatu proyek konstruksi untuk memastikan terjaminnya kesejahteraan para staf maupun pekerjanya.

\section{Rekomendasi Peningkatan Fasilitas Sementara}

Tabel 4 berikut ini menunjukkan rangkuman dari hasil pengukuran luas fasilitas sementara baik yang dilakukan dari observasi dan pengukuran langsung di lapangan, berdasarkan kajian literatur, dan rekomendasi yang dapat diberikan untuk perbaikan fasilitas sementara pada proyek pembangunan RS Edelweiss.

Tabel 4 Hasil pengukuran dan rekomendasi fasilitas sementara

\begin{tabular}{|c|c|c|c|c|c|c|}
\hline \multirow[t]{2}{*}{ No } & \multirow[t]{2}{*}{$\begin{array}{c}\text { Jenis Fasilitas } \\
\text { Sementara } \\
\end{array}$} & \multirow[t]{2}{*}{ Kode } & \multicolumn{2}{|c|}{$\begin{array}{c}\text { Luas Fasilitas } \\
\text { Sementara }\end{array}$} & \multirow[t]{2}{*}{ Rekomendasi } & \multirow[t]{2}{*}{ Asumsi } \\
\hline & & & $\begin{array}{c}\text { Kajian } \\
\text { Literatur }\end{array}$ & Pengukuran & & \\
\hline \multirow[t]{2}{*}{1} & Area induksi dan security & A1 & 17,65 & 5,12 & Bisa untuk perluasan pos satpam & \\
\hline & Pos satpam & A1 & & 2,88 & Luas minimal $4,8 \mathrm{~m}^{2}$ & 2 orang \\
\hline 2 & Area induksi 2 & $\mathrm{~A} 2$ & - & 4,64 & Bisa dihilangkan & \\
\hline 3 & Area berkumpul & $\mathrm{B}$ & 111,90 & Tidak ada & Luas minimal $58,8 \mathrm{~m}^{2}$ & 98 orang \\
\hline 4 & Kantor kontraktor & $\mathrm{C} 1$ & 57,31 & 55 & $\mathrm{OK}$ & 10 orang \\
\hline 5 & Kantor konsultan MK & $\mathrm{C} 2$ & 29,70 & 21,38 & Luas minimal $29,6 \mathrm{~m}^{2}$ & 8 orang \\
\hline 6 & Kantor direksi & $\mathrm{C} 3$ & - & 11,88 & $\mathrm{OK}$ & 2 orang \\
\hline 7 & Kantor K3 dan klinik & $\mathrm{C} 4$ & - & 10,93 & OK & 2 orang \\
\hline 8 & Kantor formwork & $\mathrm{C} 5$ & - & 14,40 & $\mathrm{OK}$ & 3 orang \\
\hline 9 & Gudang bahan & D1 & 29,70 & 22 & OK (untuk menampung zak semen) & $250 \mathrm{zak}$ \\
\hline 10 & Gudang alat & $\mathrm{D} 2$ & & 16,8 & $\mathrm{OK}$ & \\
\hline 11 & Area parkir & $\mathrm{E}$ & 47,50 & 147,81 & Pembatasan jumlah kendaraan & \\
\hline 12 & Cleaning area & $\mathrm{F}$ & 69,78 & - & Luas minimal $19,375 \mathrm{~m}^{2}$ & $\begin{array}{l}\text { Concrete } \\
\text { mixer truck }\end{array}$ \\
\hline 13 & Reinforcement area & $\mathrm{G}$ & 181,54 & 288 & OK & 144 orang/jam \\
\hline 14 & Musala staf kantor & $\mathrm{H} 1$ & 21,19 & 29,90 & $\mathrm{OK}$ & \\
\hline 15 & Musala pekerja & $\mathrm{H} 2$ & - & 4,20 & Bisa dihilangkan & \\
\hline 16 & Formwork area & $\mathrm{I}$ & 69,78 & 56 & $\mathrm{OK}$ & \\
\hline 17 & Power house & $\mathrm{J}$ & 10 & 4 & $\begin{array}{l}\text { Luas minimal } 31,5 \mathrm{~m}^{2} \text { (pertimbangan } \\
\text { keselamatan) }\end{array}$ & \\
\hline 18 & Toilet/WC staf kantor & $\mathrm{K} 1$ & - & 6,93 & OK (2 unit) & 32 orang \\
\hline 19 & Toilet/WC pekerja & $\mathrm{K} 2$ & 10 & 6,80 & Perlu penambahan 1 unit & 98 orang \\
\hline 20 & Urinoir pekerja & K3 & & 1,12 & OK (bisa pindah) & \\
\hline & $\begin{array}{l}\text { Implementasi Manajeme } \\
\text { Rumah Sakit Edelweiss } \\
\text { Dwi Adianto, Mia Wimal }\end{array}$ & $\begin{array}{l}F a \\
i K\end{array}$ & $\begin{array}{l}\text { as Konst } \\
\text { Bandung }\end{array}$ & $\begin{array}{l}\text { truksi Semen } \\
\text { - Gabriella }\end{array}$ & $\begin{array}{l}\text { tara Pada Proyek Pembangunan } \\
\text { Laurencia Liman, Yohanes Lim }\end{array}$ & 186 \\
\hline
\end{tabular}




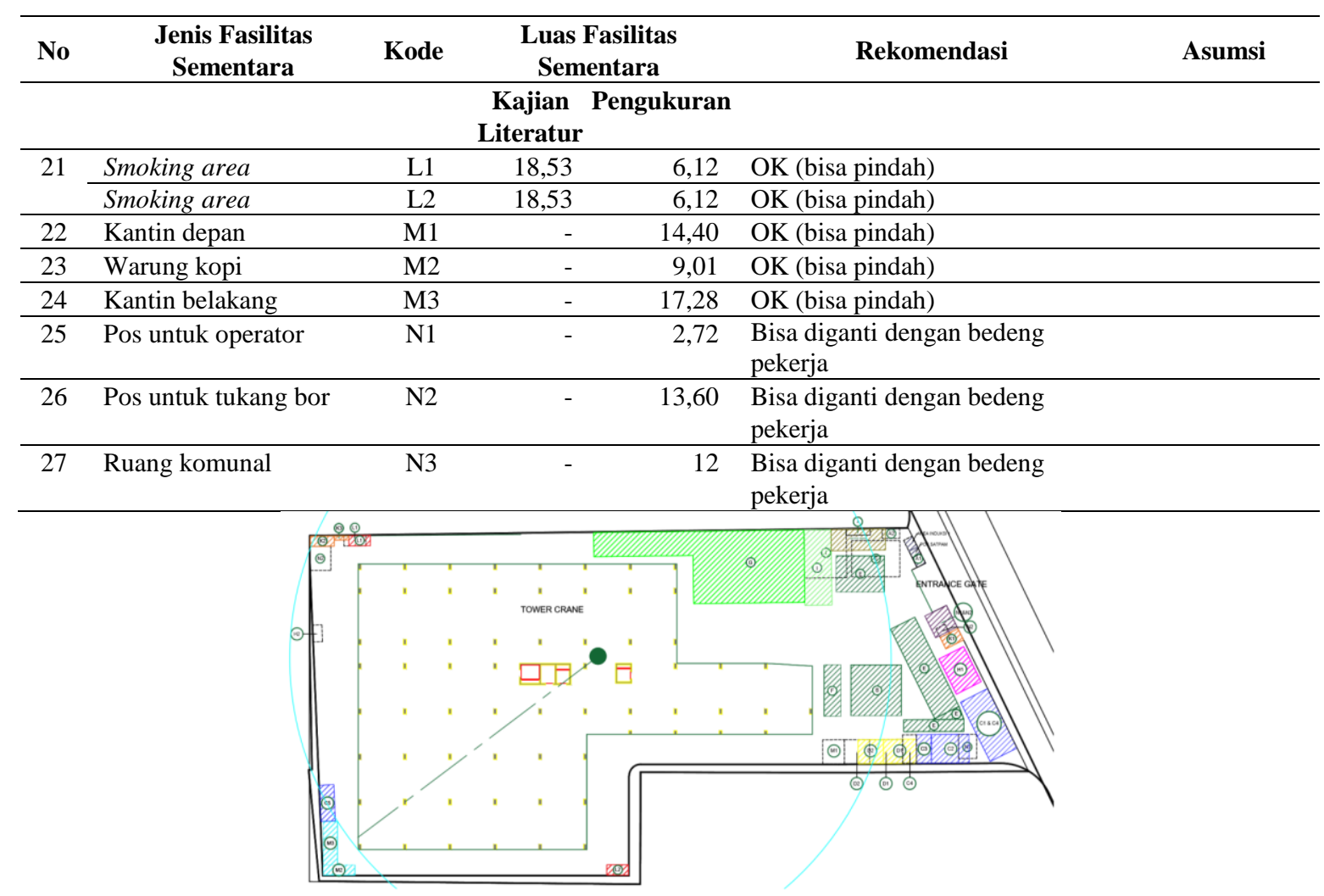

Gambar 3 Rekomendasi perbaikan site layout fasilitas sementara pada proyek pembangunan RS Edelweiss

\section{Kesimpulan}

Implementasi manajemen fasilitas sementara belum dilakukan secara maksimal akibat perencanaan yang kurang matang. Dari hasil observasi dan pengukuran langsung di lapangan, selain diperoleh perbedaan antara rancangan dan penerapannya, berhasil juga diidentifikasi bahwa jumlah, jenis, serta ukuran setiap fasilitas sementara belum semuanya dapat memenuhi kebutuhan para staf dan pekerja selama proyek berlangsung, akibatnya penambahan biaya sebesar $295,23 \%$ harus disediakan oleh kontraktor untuk mengadakan semua fasilitas sementara yang dibutuhkan, ditambah lagi, tidak semua fasilitas sementara tersebut telah sesuai dengan standar atau pedoman baku yang diperoleh sebagai hasil kajian literatur dalam penelitian ini. Dari 27 jenis fasilitas sementara, terdapat tiga fasilitas sementara yang belum mengakomodasi kebutuhan proyek konstruksi dengan baik, dari segi ukuran ruang dan ketersediaan jumlah, yaitu: kantor konsultan MK, pos satpam, dan toilet/WC pekerja. Keberadaan empat fasilitas lainnya, yakni area induksi 2, kantor K3 dan klinik, musala pekerja, serta ruang komunal juga dirasa tidak signifikan.

Perbedaan yang signifikan sebesar Rp196.090.453, atau sebesar 938\% antara perhitungan biaya pengadaan fasilitas sementara aktual di lapangan berdasarkan harga penawaran kontraktor, dengan perhitungan serupa berdasarkan AHS dan Jurnal Daftar Harga Material dan Upah Kota Bandung Tahun 2018 disebabkan oleh beberapa faktor seperti koefisien material dan pekerja, pemilihan material, besaran upah tenaga kerja, dan harga material.

Implementasi Manajemen Fasilitas Konstruksi Sementara Pada Proyek Pembangunan Rumah Sakit Edelweiss di Kota Bandung - Gabriella Laurencia Liman, Yohanes Lim Dwi Adianto, Mia Wimala 


\section{Daftar Kepustakaan}

Abotaleb, I., Nassar, K. and Hosny, O. (2015) 'Freeform-Based Construction Site Layout Optimization', in Building on Our Growth Opportunities.

Badan Standarisasi Nasional (2008) SNI: Analisa Harga Satuan.

Building and Construction Authority (BCA) (2018) Building Control Act. Available at: www.bca.gov.sg.

Calis, G. and Yuksel, O. (2019) 'A comparative study for layout planning of temporary construction facilities: Optimization by using ant colony algorithms', EG-ICE 2010 - 17th International Workshop on Intelligent Computing in Engineering, (June).

Chudley, R. and Greeno, R. (2014) Building Construction Handbook 10th Edition.

Dias, C. M. and Serra, S. M. B. (2013) 'Overview of Industrialized Technological Solutions for Temporary Facilities in Construction Sites', Portugal SB13 Contribution of Sustainable Building to meet the EU 20-20-20 Targets, (October).

Elbeltagi, E. (1987) 'Construction Site Layout Planning', Journal of Computing in Civil Engineering.

Hatem, Z. M. (2020) 'Management and Maintenance of the Welfare Facilities at Construction Sites in Irag', (January). doi: 10.13140/RG.2.2.22996.96643.

Health and Safety Executive (2015) Construction (Design and Management) Regulation. Available at: www.hse.gov.uk.

Khalafallah, A. and El-Rayes, K. (2006) 'Decision Support System for Optimizing', Joint International Conference on Computing and Decision Making in Civil and Building Engineering, (May), pp. 3001-3009.

Neufert, E. and Neufert, P. (2012) Neufert Architect's Data 4th Edition. WileyBlackwell.

Nusantara, P. B. P. (2018) Jurnal Harga Satuan Bahan Bangunan Konstruksi dan Interior.

Oral, M. et al. (2018) 'Construction site layout planning: Application of multiobjective particle swarm optimization', Teknik Dergi/Technical Journal of Turkish Chamber of Civil Engineers, 29(6), pp. 8691-8713. doi: 10.18400/tekderg.389638.

PT. PLN (2010) Buku 4 Standar Konstruksi Gardu Distribusi dan Gardu Hubung Tenaga Listrik.

Song, X. et al. (2018) 'Multistakeholder Conflict Minimization-Based Layout Planning of Construction Temporary Facilities', Journal of Computing in Civil Engineering, 32(2). doi: 10.1061/(ASCE)CP.1943-5487.0000725.

Sutt, J., Lill, I. and Müürsepp, O. (2013) The Engineer's Manual of Construction Site Planning, The Engineer's Manual of Construction Site Planning. Wiley Blackwell. doi: 10.1002/9781118556054.

Wijaya, A. S. and Putri, Y. E. (2016) 'Perencanaan Site Layout Facilities Berdasarkan Traveling Distance dan Safety Index Pada Proyek Pembangunan Hotel The Alimar Surabaya', Jurnal Teknik ITS, 5(2). doi: 10.12962/j23373539.v5i2.17245.

Copyright (c) Gabriella Laurencia Liman, Yohanes Lim Dwi Adianto, Mia Wimala

Implementasi Manajemen Fasilitas Konstruksi Sementara Pada Proyek Pembangunan Rumah Sakit Edelweiss di Kota Bandung - Gabriella Laurencia Liman, Yohanes Lim Dwi Adianto, Mia Wimala 